\title{
Genotoxicity assessment of Schinopsis brasiliensis Engl. (Sapindales: Anacardiaceae) in somatic cells of Drosophila melanogaster (Meigen, 1830) (Diptera: Drosophilidae)
}

\section{Silmara de Moraes Pantaleão ${ }^{1}$, Jéssica Adele dos Santos ${ }^{1}$, Thalyta Linacher ${ }^{1}$, Clisiane Carla de Souza Santos ${ }^{2}$, Charles dos Santos Estevam $^{2}$ and Neila Coelho da Costa ${ }^{3}$}

${ }^{1}$ Universidade Federal de Sergipe. Centro de Ciências Biológicas e da Saúde, Laboratório de Genética e Conservação de Recursos Naturais, Departamento de Biologia, São Cristóvão, Sergipe, Brasil. Email: spleao51@gmail.com.

${ }^{2}$ Universidade Federal de Sergipe, Centro de Ciências Biológicas e da Saúde, Departamento de Fisiologia, Universidade Federal de Sergipe, São Cristóvão, Sergipe, Brasil.

${ }^{3}$ Universidade Federal de Goiás, Departamento de Ciências Biológicas, Campus Catalão, Catalão, Goiás Brasil.

\begin{abstract}
Schinopsis brasiliensis Engl. (Sapindales: Anacardiaceae) has been used in the Brazilian folk medicine to treat several illnesses. However, the phytochemical profile of S. brasiliensis as well as its genotoxic potential are poorly understood, which compromises population safety regarding the medicinal use of this plant species. In this study, we analyzed the genotoxic effects of $S$. brasiliensis using the Somatic Mutation and Recombination Test (SMART) of Drosophila melanogaster. Larvae from both standard cross (ST) and high bioactivation capacity cross (HB) were exposed to different concentrations of the hydroetanolic extract and ethyl acetate fraction of $S$. brasiliensis. We analyzed wings from $D$. melanogaster according to the type and number of mutant hair. Ours results suggested no genotoxic activity of $S$. brasiliensis in D. melanogaster somatic cells.
\end{abstract}

Keywords: Genotoxicity; Baraúna; Caatinga; Tradicional medicine; SMART.
Received

May 5, 2018

Accepted

August 19, 2018

Released

August 31, 2018

Full Text Article

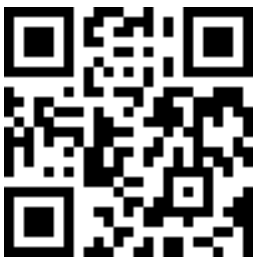

ORCID

(1) 0000-0001-6870-4360

Silmara de Moraes

Pantaleão

(1) 0000-0002-0098-7445

Jéssica Adele dos

Santos

(ㄱ) 0000-0001-6940-6891

Thalyta Linacher 


\section{Introduction}

Many plant species from Brazilian Caatinga have shown pharmacological potential, such as Erythrina velutina (Vasconcelos et al., 2007), Tabebuia aurea (Reis et al., 2014), and Ziziphus joazeir (Ribeiro et al., 2013). That fact has raised a lot of attention for plants used in the folk medicine regarding their properties and safety (Varanda, 2006; Albuquerque and Oliveira, 2007; Silva et al., 2012). However, when considering the number of native species from Caatinga that have been used by local communities, there are still few studies concerned with the composition and biological activity of most species (Vicentini et al., 2001; Liporacci et al., 2017). The genotoxic effects of medicinal plants are usually related to the concentration used by the individual (Corrêa et al., 2001; Sponchiado et al., 2016). Moreover, other aspects have to be considered when analyzing the genotoxic activity of plant species, such as the part of the plant, the age, and the presence of contaminants in the plant tissues (Saad et al., 2006).

Schinopsis brasiliensis Engl. (Anacardiaceae) is an endemic tree from Brazilian Caatinga, which occurs from the State of Bahia to the State of Paraíba (Engler, 1879). The popular commum names for this species include "baraúna", "braúna", and "quebracho" (Prado et al., 1995; Cardoso et al., 2015).

$S$. brasiliensis is used in the folk medicine to treat disturbs of the nervous system (hysteria and anxiety), inflammation, pain, and infection (Albuquerque et al., 2007; Lorenzi, 2008; Saraiva et al., 2011). Phytochemical

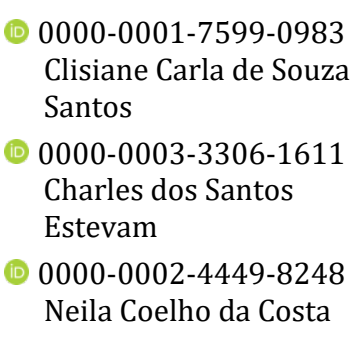

studies suggested that some species from the genus Schinopsis have a high concentration of phenolic compounds such as tannins, flavonoids, flavanones, and gallic acid (Marín-Martinez et al., 2009; Sánchez-Martína et al., 2010; Saraiva et al., 2011). Analyzing the phytochemical profile of S. brasiliensis, Almeida et al. (2010) noticed the presence of tannins, quinones, and triterpens, while Santos et al. (2014) showed that the ethyl acetate fraction from the bark of $S$. brasiliensis contains aurones, catechins, chalcones, and saponins (Santos et al., 2014). On one hand, studies demonstrated that some of those compounds have protective and antigenotoxic effect (Rodríguez-García, 2013; Manzolli et al., 2015). On the other hand, compounds such as saponins were noticed to have genotoxic effect on human lymphocytes (Kalachaveedu et al., 2014). In addition, the extract of S. brasiliensis' bark demonstrated larvicide activity against Aedes aegypti and toxic potential on Biomphalaria glabrata (Santos et al., 2014).

Despite the efficacy of S. brasiliensis in the folk medicine, there are few studies describing its composition and activity on organisms (Saraiva et al., 2009; Santos et al., 2014). The lack of scientific knowledge about this species implies on risks to people who use $S$. brasiliensis as an alternative treatment for several diseases. Considering the safety involving the consumption of medicinal plants, we found important to conduct genotoxic studies, in order to validate their use by local communities. For that finality, the Somatic Mutation and Recombination Test (SMART) in Drosophila 
melanogaster is an indicated test due to its capacity and sensibility in the identification of mutations and recombination events, besides the detection of promutagens and procarcinogens (Graf at al., 1984; Graf and Van Schaik, 1992; Panchal and Tiwari, 2017).

This study aimed to evaluate the genotoxic effects of two extracts of S. brasiliensis on somatic cells of D. melanogaster by using the Somatic Mutation and Recombination Test (SMART).

\section{Materials and methods}

\section{Plant collection}

We collected samples of S. brasiliensis in Piranhas, AL, Brazil $\left(09^{\circ} 37^{\prime} 26^{\prime \prime} \mathrm{S}\right.$ e $\left.37^{\circ} 45^{\prime} 25^{\prime \prime} \mathrm{W}\right)$. The species was identified and deposited at Federal University of Sergipe's herbarium, São Cristóvão, SE, Brazil.

\section{Extracts preparation}

The preparation of extracts consisted on keeping the plant's bark at room temperature until the material was completely dried. In sequence, we submitted the material to maceration with ethanol (90\%) for five days. We obtained the hydroethanolic extract by filtering and concentering the material under vacuum in rotatory evaporator (LS LOGEN) at $45{ }^{\circ} \mathrm{C}$. To obtain the ethyl acetate fraction, we diluted the hydroethanolic extract in methanolwater $\left(\mathrm{MeOH}: \mathrm{H}_{2} \mathrm{O}, 2: 3\right)$. The extraction was completed by adding ethyl acetate to the solution.

\section{Somatic Mutation and Recombination Test (SMART)}

The use of the SMART in Drosophila melanogaster to evaluate genotoxicity of medicinal plants and drugs is an efficient tool due to its sensibility and the genetic similarity between $D$. melanogaster and mammals (Graf et al., 1984).
Here, we used three mutant lineages of $D$. melanogaster (1) multiple wing hairs (mwh): $m w h / m w h ;(2)$ flare-3 $\left(\mathrm{flr}^{3} / \mathrm{In}\right.$ (3LR)TM3, rippsep l(3)89Aabx ${ }^{34 e}$ e $B d^{S}$; and (3) ORR; flare-3 (ORR/ORR; flr $^{3} /$ In (3LR)TM3, rippsep l(3)89Aabx ${ }^{34 e} e$ $B d^{S}$ ). Considering a proportion 2:1 for females and males, we made two different crosses: the standard cross (ST), in which flr3 individuals were females and $m w h$ individuals were males (Graf et al., 1989); and the high bioactivation cross (HB), in which ORR; flr3 individuals were females and $m w h$ individuals were males (Graf and Van Schaik, 1992).

After the eggs posture $(72 \mathrm{~h} \pm$ $4 \mathrm{~h}$ ), we placed 3rd instar larvae in plastic recipes containing food solution (1.5 g of potato powder and $5 \mathrm{~mL}$ of one of the four extract concentrations $(0.5$, 1.0, 2.0 e $4.0 \mathrm{mg} / \mathrm{mL}$ )). The controls consisted of ultrapure water (negative control) and $0.891 \mathrm{mg} / \mathrm{mL}$ of urethane (positive control). For each treatment, we made four replicates. The larvae were submitted to chronical treatment, which consisted of exposing the larvae to food solution containing the plant extract for $48 \mathrm{~h}$.

The emergent adults with the genotypes: $m w h+/+$ flr3 ou $m w h+/+$ $T M 3, B d S$ were separated and fixed in ethanol (70\%). The wings of $D$. melanogaster were fixed on slides using Faure solution (30 g of gum arabic, 20 $\mathrm{mL}$ of glycerol, $50 \mathrm{~g}$ of hydrate of chloral and $50 \mathrm{~mL}$ of water), and kept on hotplate until they were completely dry. Mutant spots were analyzed and classified according to Graf et al. (1992).

\section{Survivorship assessment}

We assessed survivorship after larvae treatment by counting the number of living flies per replicate. Percent survival was calculated for both ST and HB cross flies exposed to different concentrations of $S$. brasiliensis extracts (Figure 1). Percent survival was given by [120 (the total number of larvae exposed to a concentration) - the number of adult 
flies that emerged from the same concentration) $\mathrm{x} 100]$.

\section{Frequency of mutant hair and data analysis}

The results were submitted to statistical analysis, according to the model of multiple decisions described by Frei and Würgler (1988). The frequency of mutant hair found in the treatment was compared to the frequencies found in our positive and negative control, using the binomial conditional test of Kastenbaum and Bowman (1970), where $\alpha=0.05$. The statistical diagnoses was positive, negative, and inconclusive (Frei and Würgler, 1988).

\section{Results and discussion}

Survivorship analysis of D. melanogaster revealed no cytotoxic potential of $S$. brasiliensis extracts on both ST and HB cross flies. Percent survival of ST cross flies varied from $90 \%$ to $82.5 \%$, while percent survival of HB cross flies varied from $80 \%$ to $70 \%$, for all HEE concentrations (Figure 1). Similarly, percent survival in EAF treatments varied from $89.17 \%$ to $74.17 \%$, for ST cross flies, and from $80 \%$ to $71.67 \%$ for HB cross flies (Figure 2).

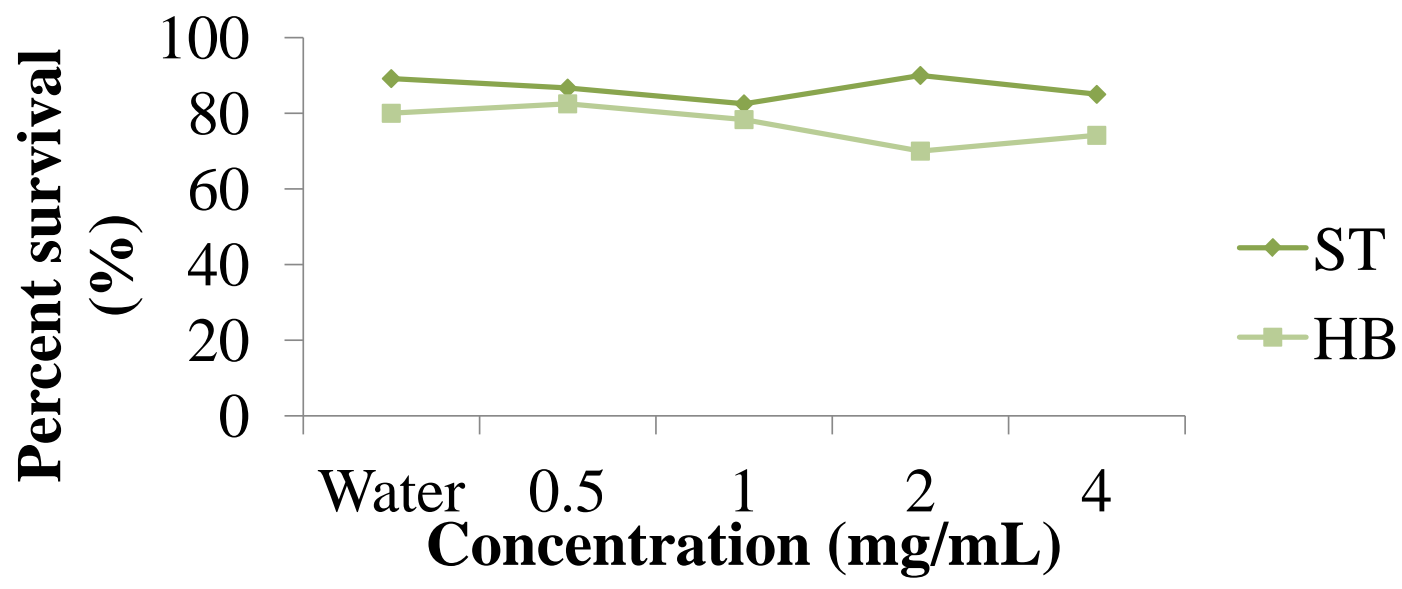

Figure 1. Survivorship curve for Drosophila melanogaster $(\mathrm{N}=120)$ exposed to the hydroetanolic extract of Schinopsis brasiliensis.

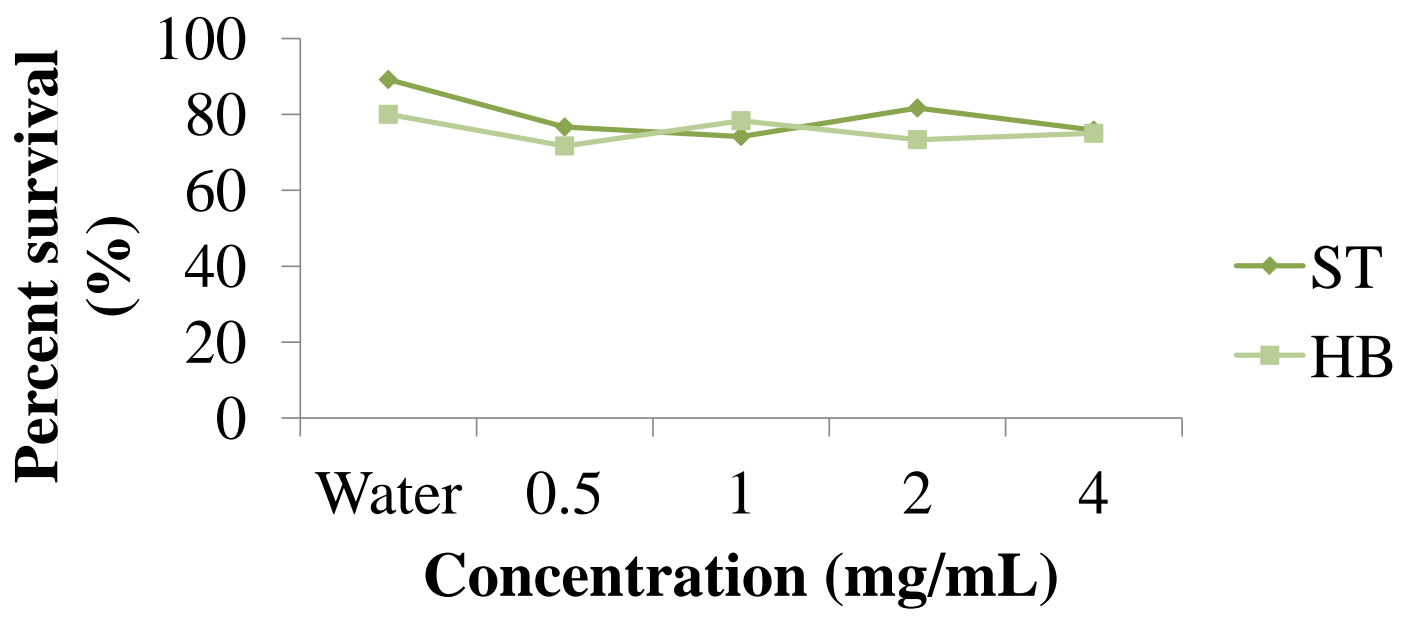

Figure 2. Survivorship curve for Drosophila melanogaster $(\mathrm{N}=120)$ exposed to the ethyl acetate fraction of Schinopsis brasiliensis. 
Results on chronic treatment of D. melanogaster larvae suggested no genotoxic effect of $S$. brasiliensis extracts at the tested concentrations. For both crosses, there was no significant difference in the frequency of mutant spots in flies treated with HEE, EAF, and negative control (Table 1 and 2).

Table 1. Summary of Results Obtained with the Drosophila Wing Spot Test (SMART) in the Marker-Heterozygous (MH) Progeny of the Standard (ST) Cross after Chronic Treatment of Larvae with EHE and FAE of the S. brasiliensis.

\begin{tabular}{|c|c|c|c|c|c|c|c|c|c|c|c|c|c|c|}
\hline \multirow{3}{*}{$\begin{array}{c}\begin{array}{c}\text { Genotype } \\
\text { Concentration } \\
\text { (mL) }\end{array} \\
\text { Negative control }\end{array}$} & \multirow{3}{*}{$\begin{array}{c}\begin{array}{c}\text { Number of } \\
\text { flies } \\
(\boldsymbol{N})\end{array} \\
30\end{array}$} & \multicolumn{12}{|c|}{ Spots per individual (number of spots) statistical diagnosis ${ }^{2}$} & \multirow{3}{*}{$\begin{array}{c}\text { Total } \\
\text { mwhe } \\
(n) \\
24\end{array}$} \\
\hline & & \multicolumn{3}{|c|}{$\begin{array}{c}\text { Small single spots } \\
\text { (1-2 cells })^{\mathrm{b}} \\
m=2\end{array}$} & \multicolumn{2}{|c|}{$\begin{array}{l}\text { Large single spots } \\
\begin{array}{c}(>2 \text { cells })^{\mathrm{b}} \\
m=5\end{array}\end{array}$} & & \multicolumn{3}{|c|}{$\begin{array}{l}\text { Large spots } \\
\qquad m=5\end{array}$} & \multicolumn{3}{|c|}{$\begin{array}{c}\text { Total spots } \\
m=2\end{array}$} & \\
\hline & & 0.57 & (17) & & 0.27 & $(8)$ & & 0,07 & (2) & & 0,80 & (24) & & \\
\hline Uretane & 20 & 1,65 & (33) & + & 0,20 & (4) & i & 0,10 & (2) & $\mathrm{i}$ & 1,95 & (39) & + & 39 \\
\hline \multicolumn{15}{|l|}{ HEE } \\
\hline 0.5 & 30 & 0,10 & (3) & - & 0,07 & (2) & - & 0,00 & (0) & i & 0,17 & (5) & - & 5 \\
\hline 1 & 30 & 0,07 & (2) & - & 0,03 & (1) & . & 0,03 & (1) & $\mathrm{i}$ & 0,13 & (4) & - & 4 \\
\hline 2 & 30 & 0,07 & (2) & . & 0,20 & (6) & i & 0,00 & (0) & i & 0,27 & (8) & - & 8 \\
\hline 4 & 30 & 0,07 & (2) & - & 0,00 & (0) & . & 0,10 & (3) & $\mathrm{i}$ & 0,17 & (5) & - & 5 \\
\hline \multicolumn{15}{|l|}{ EAF } \\
\hline 0.5 & 30 & 0,23 & (7) & - & 0,07 & (2) & - & 0,03 & (1) & $\mathrm{i}$ & 0,33 & $(10)$ & - & 10 \\
\hline 1 & & 0,17 & (5) & . & 0,13 & (4) & - & 0,07 & (2) & $\mathrm{i}$ & 0,37 & (11) & - & 11 \\
\hline 2 & 30 & 0,07 & (2) & . & 0,13 & (4) & - & 0,00 & (0) & $\mathrm{i}$ & 0,20 & (6) & - & 6 \\
\hline 4 & 30 & 0,07 & (2) & - & 0,03 & (1) & . & 0,07 & (2) & $\mathrm{i}$ & 0,17 & (5) & - & 5 \\
\hline
\end{tabular}

aStatistical diagnoses according to Frei and Wurgler (1988): +, positive; -, negative; $i$, inconclusive; $P<0.05$.

bIncluding rare $\mathrm{fl}^{3}$ single spots.

'Considering mwh clones from mwh single and twin spots.

HEE and EAF had negative results for small single spots and large single spots. For both extracts, the results on twin spots were inconclusive, fact that is usually associated to the low frequency of twin spots found in negative controls. However, analyzing the total spots the results for either HEE or EFA were negative at the standard cross (ST), which has normal metabolization activity (Graf et al., 1984).

In Table 2, we sumarized the results of the HB cross, which analyzed the activity of substances dependent on metabolization via cytocrome P450. The HB cross includes the ORR lineage, which is known by its resistence to DDT and high level of CYP450 enzymes (Pádua et

Table 2. Summary of results obtained with the Drosophila Wing Spot Test (SMART) in the Marker-Heterozygous (MH) Progeny of the High Bioactivation (HB) Cross after Chronic Treatment of Larvae with EHE and FAE of the S. brasiliensis.

\begin{tabular}{|c|c|c|c|c|c|c|c|c|c|c|c|c|c|c|}
\hline \multirow{3}{*}{$\begin{array}{c}\begin{array}{c}\text { Genotype } \\
\text { Concentration } \\
\text { (mL) }\end{array} \\
\text { Negative control }\end{array}$} & \multirow{3}{*}{$\begin{array}{c}\begin{array}{c}\text { Number of } \\
\text { fly } \\
(N)\end{array} \\
30\end{array}$} & \multicolumn{12}{|c|}{ Spots per individual (number of spots) statistical diagnosis ${ }^{a}$} & \multirow{3}{*}{$\begin{array}{c}\begin{array}{c}\text { Total } \\
\text { mwh } \\
(n)\end{array} \\
7\end{array}$} \\
\hline & & \multicolumn{3}{|c|}{$\begin{array}{c}\text { Small single spots } \\
\begin{array}{c}(1-2 \text { cells })^{b} \\
m=2\end{array}\end{array}$} & \multicolumn{3}{|c|}{$\begin{array}{l}\text { Large single spots } \\
\qquad \begin{array}{c}(>2 \text { cells })^{b} \\
m=5\end{array}\end{array}$} & \multicolumn{3}{|c|}{$\begin{array}{l}\text { Large spots } \\
\qquad m=5\end{array}$} & \multicolumn{3}{|c|}{$\begin{array}{l}\text { Total spots } \\
m=2\end{array}$} & \\
\hline & & 0,23 & $(07)$ & & 0,0 & $(0)$ & & 0,00 & (0) & & 0,23 & (7) & & \\
\hline $\begin{array}{c}\text { Uretane } \\
\text { HEE }\end{array}$ & 20 & 2,35 & $(47)$ & + & 0,80 & $(16)$ & + & 0,30 & (6) & + & 3,15 & (63) & + & 63 \\
\hline 0.5 & 30 & 0,10 & (3) & - & 0,03 & (1) & i & 0.00 & $(0)$ & $\mathrm{i}$ & 0,13 & (4) & - & 4 \\
\hline 1 & 30 & 0.40 & (12) & - & 0.13 & (4) & i & 0.03 & (1) & i & 0,57 & (17) & - & 17 \\
\hline 2 & 30 & 0,20 & (6) & - & 0.13 & (4) & $\mathrm{i}$ & 0,03 & (1) & i & 0,37 & (11) & - & 11 \\
\hline 4 & 30 & 0,27 & (8) & - & 0,13 & (4) & $\mathrm{i}$ & 0,10 & (3) & $\mathrm{i}$ & 0,50 & (15) & - & 15 \\
\hline EAF & & & & & & & & & & & & & & \\
\hline 0.5 & 30 & 0,43 & (13) & - & 0,03 & (1) & 1 & 0,03 & (1) & i & 0,50 & (15) & - & 15 \\
\hline 1 & 30 & 0,07 & (2) & - & 0,13 & (4) & i & 0,03 & (1) & $\mathrm{i}$ & 0,23 & (7) & - & 7 \\
\hline 2 & 30 & 0,20 & (6) & - & 0,10 & (3) & 1 & 0,00 & $(0)$ & 1 & 0,30 & $(9)$ & - & 9 \\
\hline 4 & 30 & 0,27 & (8) & - & 0,10 & (3) & $\mathrm{i}$ & 0,00 & $(0)$ & i & 0,37 & (11) & - & 11 \\
\hline
\end{tabular}

aStatistical diagnoses according to Frei and Wurgler (1988): +, positive; -, negative; I, inconclusive; $\mathrm{P}<0.05$.

bIncluding rare $\mathrm{flr}^{3}$ single spots.

cConsidering mwh clones from mwh single and twin spots. 
al., 2013). This fact enhances fly sensibility to promutagens and procarcinogens, which allows the identification of subtances with indirect activity. For the HB cross our results on large single spots and twin spots were inconclusive for all concentrations of HEE and EAF. However, those results have low biological significance, considering that the frequency of total spots we found in the HB cross flies exposed to HEE and EAF were lower than the frequencies found in the positive control.

The analysis of the transheterozygous progeny from both ST and HB crosses exposed to uretan showed that the negative results obtained in the treatments with HEE and EAF are not false-negatives.

Machado (2012) verified that S. brasiliensis extract had on its phytochemical composition, substances that were able to inhibit development of Staphylococcus aureus, Escherichia coli, Klebsiella pneumoniae and Pseudomonas aeruginosa, suggesting antimicrobial properties of $S$. brasiliensis. Santos et al. (2014) noticed that the ethyl acetate fraction of $S$. brasiliensis had larvicide activity on Aedes aegypti and toxic effect on Biomphlaria glabrata. In addition, the authors classified tannins as the main phenolic compounds in the bark of S. brasiliensis. It is known that the amount of tannins found in wild plants is usually higher than the amount found in domesticated plants (Hagerman and Butler, 1991). This fact is understood as an adaptation to herbivory, seeing that tannins create a negative response to predation by promoting antinutricional and toxic effects on herbivores through the coagulation of mucoproteins and consequent inhibition of digestion (Harborne, 1988).

On the other hand, phenolic compounds have antioxidant properties, once those substances have the ability of donating hydrogen and electrons due to the presence of stable radicals that avoid the oxidation of compounds (Degáspari and Waszczynskyj, 2004). Moreover, an antigenotoxicity study regarding the use of pro-anthocyanins (condensed tannins) extracted from Vittis vinifera seeds suggested a protective effect induced by the substance on genotoxic damages caused by doxorubicin hydrochloride (an antracicline that acts on the formation of free radicals by interfering the enzyme topoisomerase II) (Rezende et al., 2009). Thus, future researches would focus on the antigenotoxic potential of S. brasiliensis.

Our results were statiscally nonsignificant for both ST and HB crosses, which indicates that the two extracts of $S$. brasiliensis had neither genotoxic effect on D. melanogaster somatic cells with low metabolization activity, nor genotoxic effect on D.melanogaster somatic cells with high metabolization activity, regarding the promotion of mutation, deletion, non-disjunction and mitotic recombination.

\section{Conclusions}

The results presented in our preliminary study suggest no genotoxic effect of S. brasiliensis on D. melanogaster. However, considering other organisms is a step necessary to guarantee the safe use of $S$. brasiliensis by the population or even to validate its use as a medicine. Additional studies would also focus on the anti-genotoxic potential of $S$. brasiliensis in order to explore the pharmacological potential of this species.

\section{Acknowledgments}

CSE and CCSS coordinate the extract preparation and biological studies. NCS and SMP contributed to design the study supervised the laboratory work execution and critical reading of the manuscript. JASS, TLGSR, CCSS, MRB and PS contributed in running the laboratory work, analysis of the data and drafted the paper. JASS contributed in plant identification and herbarium confection. 


\section{Conflict of interest}

The authors declare that they have no competing interests.

\section{References}

Albuquerque, U. P.; Oliveira, R. F. Is the useimpact on native caatinga species in Brazil reduced by the high species richness of medicinal plants? Journal of Ethnopharmacology, v. 113, no. 1, p. 156170, 2007. https://doi.org/10.1016/j.jep. 2007.05.025

Almeida, C. F. C. B. R.; Ramos, M. A.; Amorim, E. L. C.; Albuquerque, U. P. A comparison of knowledge about medicinal plants for three rural communities in the semi-arid region of Northeast of Brazil. Journal of Ethnopharmacology, v. 127, no. 3, p. 674684 , 2010. https://doi.org/10.1016/j.jep. 2009.12.005

Braga, R. Plantas do Nordeste, especialmente do Ceará. 3. ed. Fortaleza: Escola Superior de Agricultura de Mossoró, 1976.

Cardoso, M. P.; David, J. M.; David, J. P. A new alkyl phenol from Schinopsis brasiliensis. Natural Product Research, v. 19, no. 5, p. 431-433, 2005. https://doi.org/10.1080/ 14786410512331330684

Corrêa, A. D.; Batista, R. S.; Quintas, L. E. M. Plantas medicinais do cultivo à terapêutica. 5. ed. Rio de Janeiro: Vozes, 2001.

Degáspari, C. H.; Waszczynskyj, N. Propriedades antioxidantes de compostos fenólicos. Visão Acadêmica, v. 5, no. 1, p. 3340, 2004. https://doi.org/10.5380/ acd.v5i1.540

Engler, A. Anacardiaceae. In: Martius, C. F. P.; Eichler, A. G. (Eds.). Flora Brasiliensis. Munchen: Wien, Leipzig, 1876. v. 12. Pars 2. p. 367-418. https://doi.org/10.5962/bhl. title. 454

Frei, H.; Würgler, F. E. Statistical methods to decide whether mutagenicity test data from Drosophila assays indicate a positive, negative or inconclusive result. Mutation Research/Environmental Mutagenesis and Related Subjects, v. 203, p. 297-308, 1988. https://doi.org/10.1016/0165-1161 (88)90019-2
García-Rodríguez, M. C.; Nicolás-Méndez, T.; Montaño-Rodríguez, A. R.; AltamiranoLozano, M. A. Antigenotoxic effects of (-)epigallocatechin-3-gallate (EGCG), quercetin, and rutin on chromium trioxide-induced micronuclei in the polychromatic erythrocytes of mouse peripheral blood. Journal of Toxicology and Environmental Health, Part A, v. 77, no. 6, p. 324-336, 2014. https://doi.org/10.1080/15287394.2013.86 5006

Graf, U.; Frei, H.; Kägi, A.; Katz, A. J.; Würgler, F. E. Thirty compounds tested in the Drosophila wing spot test. Mutation Research/Genetic Toxicology, v. 222, no. 4, p. 359-373, 1989. https://doi.org/10.1016/ 0165-1218(89)90112-2

Graf, U.; Van Schaik, N. Improved high bioactivation cross for the wing somatic mutation and recombination test in Drosophila melanogaster. Mutation Research/Environmental Mutagenesis and Related Subjects, v. 271, no. 1, p. 59-67, 1992. https://doi.org/10.1016/0165-1161 (92)90032-H

Graf, U.; Würgler, F. E.; Katz, A. J.; Frei, H.; Juon, H.; Hall, C. B.; Kale, P. G. Somatic mutation and recombination test in Drosophila melanogaster. Environmental and Molecular Mutagesis, v. 6, no. 2, p. 153188, 1984. https://doi.org/10.1002/em. 2860060206

Hagerman, A. E.; Butler, L. G. Tannins and lignins. In: Rosenthal, G. A.; Berenbaum, M. R. Herbivores: Their interactions with secondary plant metabolites; the chemical participants. 2. ed. New York: Academic Press, 1991.

Harborne, J. B. Phytochemical methods: A guide modern techniques of plant analysis. 2. ed. London: Chapman and Hall, 1988.

Kalachaveedu, M.; Papacchan, S.; Sanyal, S.; Koshy, T.; Telapolu, S. Isolation and evaluation of cytogenetic effect of Brahmi saponins on cultured human lymphocytes exposed in vitro. Natural Product Research, v. 29, no. 12, p. 1118-1121, 2015. https://doi.org/10.1080/14786419.2014.97 9416

Kastenbaum, M. A.; Bowman, K. O. Tables for determining the statistical significance of mutation frequencies. Mutation Research/Fundamental and Molecular Mechanisms of Mutagenesis, v. 9, p. 527- 
549, 1970. https://doi.org/10.1016/00275107(70)90038-2

Liporacci, H. S. N.; Hanazaki, N.; Ritter, M. R.; Araujo, E. L. Where are the Brazilian ethnobotanical studies in the Atlantic Forest and Caatinga? Rodriguésia, v. 68 , no. 4 , p. 1225-1240, 2017. https://doi.org/ 10.1590/2175-7860201768407

Lorenzi H. Árvores brasileiras: manual de identificação e cultivo de plantas arbóreas do Brasil. 5. Ed. São Paulo: Instituto Plantarum, 2008. v. 1.

Machado, S. E. F. Avaliação da atividade antimicrobiana dos extratos fracionados de casca e folha da Schinopsis brasiliensis Engler através da análise comparativa entre os métodos de difusão em disco e de cavidade em placa. Campina Grande: Universidade Estadual da Paraíba, 2012. (Undergraduate dissertation). Available from: <http://dspace.bc.uepb.edu.br:8080/ xmlui/handle/123456789/2725>. Accessed on: Apr. 23, 2018

Manzolli, E. S.; Serpeloni, J. M.; Grotto, D.; Bastos, J. K.; Antunes, L. M.; Barbosa, F.; Barcelos, G. R. M. Protective effects of the flavonoid chrysin against methylmercuryinduced genotoxicity and alterations of antioxidant status, in vivo. Oxidative Medicine and Cellular Longevity, v. 2015, article ID 602360, p.1-7, 2015. https://doi.org/10.1155/2015/602360

Marín-Martinez, R.; Veloz-Garcia, R.; VelozRodriguez, R.; Guzmán-Maldonado, S.; Loarca-Pina, G.; Cardador-Matinez, A.; Guevara-Olvera, L.; Miranda-López, R.; Torres-Pacheco, I.; Pérez Pérez, C.; HerreraHernández, G.; Villaseñor-Ortega, G. F.; González-Chavira, M.; Guevara-Gonzalez, R. G. Antimutagenic and antioxidant activities of quebracho phenolics (Schinopsis balansae) recovered from tannery wastewaters. Bioresource Technology, v. 100, no. 1, p. 434-439, 2009. https://doi.org/ 10.1016/j.biortech.2008.05.029

Pádua; P. F. M. R.; Dihl, R. R.; Lehmann, M.; Abreu, B. R. R.; Richter, M. F.; Andrade, H. H. R. Genotoxic, antigenotoxic and phytochemical assessment of Terminalia actinophylla ethanolic extract. Food and Chemical Toxicology, v. 62, p.521-527, $2013 . \quad$ https://doi.org/10.1016/j.fct. 2013.09.021

Panchal, K.; Tiwari, A. K. Drosophila melanogaster "a potential model organism" for identification of pharmacological properties of plants/plant-derived components. Biomedicine \& Pharmacotherapy, v. 89 , p. 1331-1345, 2017. https://doi.org/10.1016/j.biopha. 2017.03.001

Prado, M. C. G.; Barbosa, D. C. A.; Alves, J. L. H. Aspecto morfo-estruturais da unidade de dispersão de Schinopsis brasiliensis Engl. "Baraúna" (Anacardiaceae). Boletim da Sociedade Broteriana, v. 67 , no. 2, p. 187 197, 1995.

Reis, F. P.; Bonfa, I. M. S.; Cavalcante, R. B.; Okoba, D.; Vasconcelos, S. B. S.; Candeloro, L.; Oliveira Filiu, W. F.; Duenhas Monreal, A. C.; Silva, V. J.; Santa Rita, P. H.; Carollo, C. A.; Toffoli-Kadri, M. C. Tabebuia aurea decreases inflammatory, myotoxic and hemorrhagic activities induced by the venom of Bothrops neuwiedi. Journal of Ethnopharmacology, v. 158, Part A, p. 352-357, 2014. https://doi.org/10.1016/j.jep.2014.10.045

Rezende, A. A. A.; Graf, U.; Guterres, Z. R.; Kerr, W. E.; Spanó, M. A. Protective effects of proanthocyanidins of grape (Vitis vinifera L.) seeds on DNA damage induced by Doxorubicin in somatic cells of Drosophila melanogaster. Food Chem. Toxicol., v. 47, no. 7, p. 1466-1472, 2009. https://doi.org/ 10.1016/j.fct.2009.03.031

Ribeiro, B. D.; Alviano, D. S.; Barreto, D. W.; Coelho, M. A. Z. Functional properties of saponins from sisal (Agave sisalana) and juá (Ziziphus joazeiro): critical micellar concentration, antioxidant and antimicrobial activities. Colloids and Surfaces A: Physicochemical and Engineering Aspects, v. 436, p. 736-743, 2013. https://doi.org/ 10.1016/j.colsurfa.2013.08.007

Saad, B.; Azaizeh, H.; Abu-Hijleh, G.; Said, O. Safety of traditional Arab Herbal Medicine. Evidence-Based Complementary and Alternative Medicine, v. 3, no. 4, p. 433-439, 2006. https://doi.org/10.1093/ecam/nel058

Sánchez-Martín, J.; González-Velasco, M.; Beltrán-Heredia, J. Surface water treatment with tannin-based coagulants from Quebracho (Schinopsis balansae). Chemical Engineering Journal, v. 165, no. 3, p. 851858, 2010. https://doi.org/10.1016/j.cej. 2010.10 .030

Santos, C. C. S.; Araújo, S. S.; Santos, A. L. L. M.; Almeida, E. C. V.; Dias, A. S.; Damascena, N. P.; Santos, D. M.; Santos, M. I. S.; Júnior, K. A. L. R.; Pereira, C. K. B.; Lima, A. C. B.; Shan, A. Y. 
K. V.; Sant'ana, A. E. G.; Estevam, C. S.; Araujo, B. S. Evaluation of the toxicity and molluscicidal and larvicidal activities of Schinopsis brasiliensis stem bark extract and its fractions. Revista Brasileira de Farmacognosia, v. 24, no. 3, p. 298-303, 2014. https://doi.org/10.1016/j.bjp. 2014.07.006

Saraiva, A. M.; Castro, R. H. A.; Cordeiro, R. P.; Peixoto Sobrinho, T. J. S.; Castro, V. T. N. A.; Amorim, E. L. C.; Xavier, H. S.; Pisciottano, M. N.C. In vitro evaluation of antioxidant, antimicrobial and toxicity properties of extracts of Schinopsis brasiliensis Engl. (Anacardiaceae). African Journal of Pharmacy and Pharmacology, v. 5, no. 1, p. 1724-1731, 2011. https://doi.org/ 10.5897/AJPP11.428

Silva, M. S.; Brandão, D. O.; Chaves, T. P.; Formiga Filho, A. L.; Costa, E. M. M. B.; Santos, V. L.; Medeiros, A. C. Study bioprospecting of medicinal plant extracts of the semiarid Northeast: Contribution to the control of oral microorganisms.

Evidence-Based Complementary and Alternative Medicine, v. 2012, article ID 681207, p. 1-6, 2012. https://doi.org/10.1155/2012/681207

Sponchiado, G.; Adam, M. L.; Silva, C. D.; Soley, B. S.; Mello-Sampayo, C.; Cabrini, D. A.; Correr,
C. J.; Otuki, M. F. Quantitative genotoxicity assays for analysis of medicinal plants: A systematic review. Journal of Ethnopharmacology, v. 178 , no. 3, p. 289296, 2016. https://doi.org/10.1016/j.jep. 2015.10.026

Varanda, E. A. Atividade mutagênica de plantas medicinais. Revista de Ciências Farmacêuticas Básica e Aplicada, v. 27, no. 1, p.1-7, 2006. Available from: <http://serv-bib.fcfar.unesp.br/seer/ index.php/Cien_Farm/article/viewArticle/35 5>. Accessed on: Apr. 23, 2018.

Vasconcelos, S. M.; Lima, N. M.; Sales, G. T.; Cunha, G. M.; Aguiar, L. M.; Silveira, E. R.; Rodrigues, A. C.; Macedo, D. S.; Fonteles, M. M.; Sousa, F. C.; Viana, G. S. Anticonvulsant activity of hydroalcoholic extracts from Erythrina velutina and Erythrina mulungu. Journal of Ethnopharmacology, v. 110, no. 2, p. 271-274, 2007. https://doi.org/ 10.1016/j.jep.2006.09.023

Vicentini, V. E. P.; Camparoto, M. L.; Teixeira, R. O.; Mantovani, M. S. Averrhoa carambola L., Syzygium cumini (L.) Skeels and Cissus sicyoides L.: Medicinal herbal tea effects on vegetal and test systems. Acta Scientarium, v. 23, p. 593-598, 2001. https://doi.org/ 10.4025/actascibiolsci.v23i0.2716

License information: This is an open-access article distributed under the terms of the Creative Commons Attribution License, which permits unrestricted use, distribution, and reproduction in any medium, provided the original work is properly cited. 